\title{
Classical and modern concepts of corporate governance (Stewardship Theory and Agency Theory)
}

Beata Glinkowska Ph.D.

University of Lodz, Department of Management

Prof. Bogusław Kaczmarek University of Lodz, Department of Management

\section{Introduction}

The power and governance structure in companies is one of research streams in management theory.

A hypothesis, that has already been partially proved by empirical research, states that "the underlying cause of a crisis situation in a company is the weakness of ownership supervision, especially insufficient autonomy of the supervisory board" (Jeżak 2010, pp. 5163).

The existing research shows a direct relationship between "the level of supervisory board's self-reliance and company performance - the more independent the board, the higher the quality of management and the better company performance"(Daily and Dalton 1994, p. 646).

According to general assumptions of the corporate governance theory the primary task of supervisory board (board of directors) is "assessment of actions taken by members of the board, evaluation of their management skills and their input into meeting shareholders' expectations"(Urbanek 2005, p. 301). 
This article will be showcasing a classic and modern approach to the role of supervisory boards in the process of efficiency improvement in companies. The article is based on analysis of the most cited literature approaches regarding this subject.

\section{Classical approach to the role of supervisory board in the management process}

Corporate governance can be defined in many ways. In the most basic understanding corporate governance is the sum of management and supervision rules for international enterprises (corporations). Statutory (formal) authorities

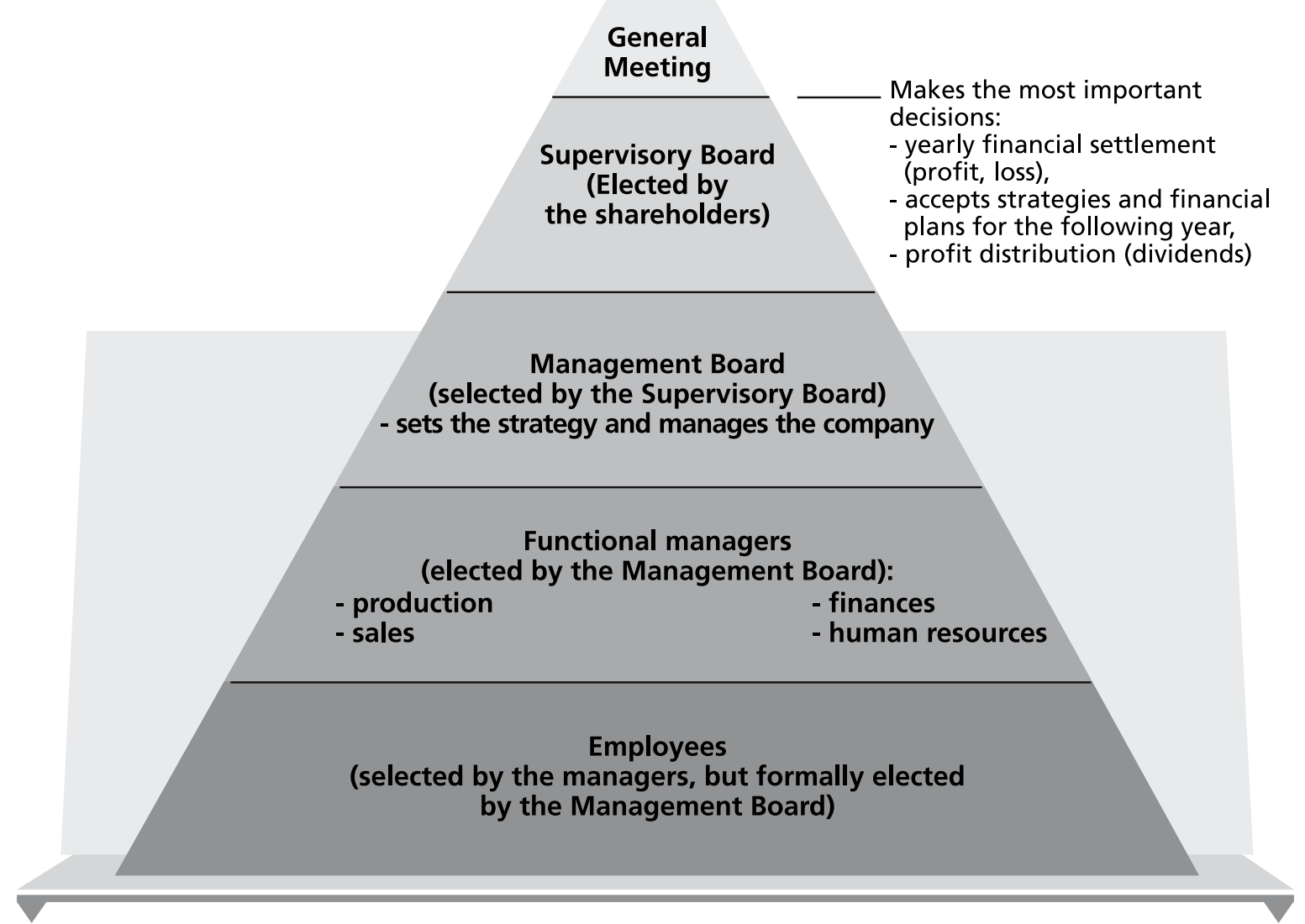

Figure 1. Authorities in joint-stock companies

Source: own study 
in joint-stock companies (vast majority of international enterprises takes the form of joint-stock companies) consist of three bodies: general meeting of shareholders, supervisory board, and management board. That is further illustrated on figure 1.

It can be assumed that the general meeting is the legislative body, supervisory board the controlling body, and the management board the executive body.

The functioning of Supervisory Boards arouses the most controversy. Traditionally, the basic task of a Supervisory Board "is constant supervision over the activities of a company in all the areas of its activity. At the same time, the Supervisory Board does not have any authority over the manner in which the management board is operating. Its core duties are: verification of financial statements with account books, documents, and with factual circumstances; evaluation of management board's motions on profit or loss distribution; compiling a written report on the results of these evaluations and presenting it on the annual general meeting" (Jeżak 2010, p. 55).

The Supervisory Board can appoint and dismiss (or suspend rights of) management board's members by determining the number of board members, their working conditions, scope of duties and responsibilities.

Thus, it can be stated that in the traditional understanding the Supervisory Board has two main functions: instituting function and supervisory function.

\section{Modern concepts of board functioning in corporate governance}

The currently promoted so-called modified approach states that expanding the authority and competencies (scope of duties) of the Supervisory Board is crucial to maintaining its efficiency, especially in regard to preventing (diagnosing) and overcoming crisis situations.

E. Gutenberg (1980) points to the following Supervisory Board functions:

- supervision,

- consulting,

- decision-making,

- cooperation and information exchange,

- coordination.

Such a significant expansion of Supervisory Board's functions aims to put into use to the fullest extent board's members' intellectual potential, that is their qualifications, experiences and skills. Especial emphasis is being put on the following new tasks of supervisory boards: yearly evaluations of the company's situation (economic, financial, market, and organisational); identifying potential 
threats to the current market position and ways to prevent these threats. The Supervisory Board elected by the General Meeting as a representation for all shareholders - the source of company's financial capital - should primarily analyse and evaluate the way said capital is used and how it translates into positive economic and financial results of the company.

At the same time the Supervisory Board should be also presenting the General Meeting an analysis of the so-called non-financial factors such as: product life-cycle (i.e. level of product renewal), talent management, development of information and communication technologies systems, motivating systems and their relation with work quality, relationship marketing - contact with suppliers, customers, cooperants, and key stakeholders. J. Jeżak states that "(..) only the sum of financial and non-financial factors can be the basis for evaluation of company's well-being by the supervisory board" (Jeżak 2010, p. 62).

Theoretical and model concepts on corporate governance based on practical research are very interesting, especially when confronted with economic reality. They are not derived from management but from institutional economics. These concepts are: agency theory and stewardship theory. In the most basic understanding, they describe the behaviours of managers - members of supervisory boards - and the role of supervisory boards in relation to the management board of a company. The most important aspects emphasized by the agency theory and stewardship theory are shown on tab. 1.

Table 1. The most important aspects emphasized by the agency theory and stewardship theory

\begin{tabular}{|c|c|}
\hline Agency Theory & Stewardship Theory \\
\hline $\begin{array}{l}1 \text { An emphasis on an efficient governance } \\
\text { mechanism of the Supervisory Board over } \\
\text { the Management Board (financial decisions } \\
\text { made by the Management Board exceeding a } \\
\text { certain amount have to be signed off on by the } \\
\text { Supervisory Board) }\end{array}$ & $\begin{array}{l}\text { 1. The Supervisory Board gives credit and } \\
\text { appreciation for the Management Board. } \\
\text { 2. The relation between Supervisory Board and } \\
\text { Management Board is based on trust. } \\
\text { 3. The stewardship theory's philosophy is based } \\
\text { on McGregor's Theory Y. }\end{array}$ \\
\hline $\begin{array}{l}\text { 2. The Supervisory Board constantly controls } \\
\text { activities of the Management Board. } \\
\text { 3. Focus is put on maximising the usefulness }\end{array}$ & $\begin{array}{l}\text { 4. The key motivator for Management Board } \\
\text { members is getting satisfaction form a job well } \\
\text { done. }\end{array}$ \\
\hline $\begin{array}{l}\text { of Management Board members and } \\
\text { shareholders, on behalf of whom they are } \\
\text { acting - the agent - principal problem. }\end{array}$ & $\begin{array}{l}\text { 5. Pro-organisation behaviours are highly valued. } \\
\text { 6. There are no conflicts between the Management } \\
\text { Board and shareholders. }\end{array}$ \\
\hline $\begin{array}{l}\text { 4. The agency theory's philosophy is based on } \\
\text { McGregor's Theory X. }\end{array}$ & $\begin{array}{l}\text { 7. Financial factors are not the key motivator for } \\
\text { employees. }\end{array}$ \\
\hline
\end{tabular}

87 
5. The Supervisory Board represents the owners and responds to them.

6 . The work motivators are solely financial.

7. Managers' holding shares is a cost that must have positive results.

8. Situational factors are not considered by managers in their decision-making, only economic rationalism stands.
8. There are no reasons for the Supervisory Board to implement costly motivators as satisfactory remuneration is enough.

Source: own work

The "philosophy" characteristics of stewardship theory and agency theory in corporate governance are juxtaposed on tab. 2 .

It may seem that both agency theory and stewardship theory are derived from different concepts of a "model person". In agency theory we are presented with a rational individual that by furthering their own interests is aiming to maximise own usefulness.

The stewardship theory seems to be strongly rooted in organisational psychology and sociology, especially in McGregor's Theory Y. In 1960, McGregor presented two opposite approaches of managers to employees. These approaches were named Theory $X$ and Theory $Y$. They are describing the way employees are perceived by managers ${ }^{1}$. Stewardship theory is focusing on managerial behaviour. It states that the key motivating factor for managers is getting satisfaction from a job well done. Thus, their behaviour is pro-organisational and in line with organisation's interests. There is no conflict between managers and shareholders. That conflict in turn is the essence of the problems described by the agency theory.

Table 2. The philosophy of Agency Theory and Steward Theory comparison

\begin{tabular}{l|l|l}
\hline Criteria & Agency Theory & Stewardship Theory \\
\hline Theoretical basis & Economics & $\begin{array}{l}\text { Organisational psychology and } \\
\text { sociology }\end{array}$ \\
\hline Model person & Homo economicus & Self-actualizing person \\
\hline
\end{tabular}

1 Theory $X$ states that a regular employee does not like his work and is avoiding it. Whereas, theory $\mathrm{Y}$ assumes that a regular employee considers work to be a natural part of life, likes it and has an innate tendency to be creative and innovative. 


\begin{tabular}{l|l|l}
\hline Behaviours & Opportunism & Pro-organisational \\
\hline $\begin{array}{l}\text { General approach to the } \\
\text { uncertainty of managerial } \\
\text { behaviour }\end{array}$ & Distrust & Trust \\
\hline Manager motivators & Financial (material, external) & Non-financial (internal) \\
\hline $\begin{array}{l}\text { Owner - manager } \\
\text { relationship }\end{array}$ & Conflict of interests & Mutual interests \\
\hline $\begin{array}{l}\text { Typical recommendations } \\
\text { for corporate governance }\end{array}$ & $\begin{array}{l}\text { Monitoring as the most } \\
\text { important role of the } \\
\text { Supervisory Board } \\
\text { Director's independence } \\
\text { Stimuli }\end{array}$ & $\begin{array}{l}\text { Consulting as the most important role } \\
\text { of the Supervisory Board } \\
\text { Wide range of management's } \\
\text { authority } \\
\text { Fixed salary }\end{array}$ \\
\hline
\end{tabular}

Source: Grundei 09/2008;58, p. 143

When it comes to the functions of supervisory boards in companies, the agency theory puts emphasis on constant monitoring of management board's activities, whereas in the stewardship theory the primary function of the supervisory board in relation to the management board is to lend support, give advice, share experience and skills.

What is the biggest difference between these two theories?

It is the approach to motivation.

In agency theory, "agent" motivators are solely financial. This is mainly a result of the necessity to align agent behaviour with shareholders' interests. That is why manager's owning shares of the company is a chief motivator. That is a component of the company's costs! The stewardship theory states that there is no need to implement "costly" motivators. The so-called "satisfactory remuneration" is enough. Psychological and situational context in corporate governance is also considered in both agency theory and stewardship theory.

In agency theory, the psychological factor (i.e. motivation) is a result of financial needs. However, in stewardship theory, higher level needs (progress, achievements, self-actualization) are the source of motivation.

The situational factors in stewardship theory are: trust, engagement, collectivism and low power distance. In contrast, in the agency theory these factors are: control mechanisms, individualism, and high power distance.

3.1 The Theory of Agency prevails in the Anglo-Saxon system of supervision. By default it assumes the lack of full trust between the board of directors (the 
control's team) and the management (the management team). An opposite assumption comes from the theory of Steward, more recognized in corporate governance systems in Europe and Japan. It says that the conflict of interests is always present, but it also emphasizes that the board members will always prioritize and take care of the interests of company, for the sake of their position in the market of managers and also because it determines the perspective of their further promotion and development.

3.2 A unique concept of functioning of the Supervisory Boards is created by A. Peszko (2006, p. 241). The author presents the idea in a form of two opposing models: the closed model (insider model) and open model (outsider model). "The difference between the models lays in selection of a-mechanisms used to discipline managers. The closed model is based on high professional competence of the supervisory board; the open model the supervision mechanisms relies on large role of external factors such as an acquisitions' market, high level of competitiveness on the market of goods and services and a strong influence of public opinion shaped by the mass media. Anglo-Saxon system is definitely more open, whereas the European is rather closed." (Peszko, 2006, p. 209).

3.3 M. Jerzemowska (2010, p. 37) claims that "there is no global, mandatory regulation of corporate governance". One shall agree with this position, but at the same time shall be pointed out that the rules regulating corporate governance are in agreement with the sets of standards and guidelines for corporate governance (OECD in 1999 and amended in 2004) also including such issues as:

- the rights of shareholders and key ownership functions,

- equal treatment of shareholders,

- the role of stakeholders in corporate governance processes,

- the responsibility of the company's body.

\section{Conclusion}

The concepts presented and analysed here show the models of functioning of corporate governance (modified functions of the supervisory board, Agencies Theory, the Steward's Theory, closed model, open model, guidelines and standards of the OECD) indicate that there are anthe attempts to modify the efficiency of the supervisory boards (corporate governance). One could say that the current state of analysis and research on corporate governance does not allow for far-reaching proposals and guidelines leading to "optimal model" of corporate governance functioning, but it seems that these are necessary steps towards finding such a model. 


\section{Summary}

Classical and modern concepts of corporate governance (Stewardship Theory and Agency Theory)

The main issues in efficiency of a company as an organisation are relations between the Supervisory Board and the Management Board of a company, and the methods of functioning of Supervisory Boards in governance systems of a company.

The classical and modern approach to the role, place, and importance of corporate governance presented in this article, is yet another prompt to continue searching for the optimum in the organisational, economical, and social meaning.

Keywords: corporate governance, supervisory of board, efficiency, Agency Theory, Stewardship Theory

\section{Streszczenie}

\section{Klasyczne i współczesne koncepcje nadzoru korporacyjnego} (teoria agencji i Stewarda)

Relacje między Radą Nadzorczą z zarządem przedsiębiorstwa, sposoby funkcjonowania Rad w systemie władzy przedsiębiorstwa to jedne z najważniejszych problemów sprawności działania przedsiębiorstwa jako organizacji.

Przedstawione w opracowaniu klasyczne i współczesne podejście do roli, usytuowania i znaczenia funkcjonowania nadzoru korporacyjnego to jeszcze jeden głos w kierunku poszukiwań tego optimum w znaczeniu zarówno organizacyjnym, ekonomicznym i społecznym.

\section{Słowa}

kluczowe: nadzór korporacyjny, rada nadzorcza, sprawność, teoria agencji, teoria stewarda

\section{References}

1. Daily C.M., Dalton, D.R. (1994), Corporate governance and the bankrupt firm, "Strategic Management Journal" Vol. 15, No. 8.

2. Grundei J. (2008), Are managers agents or stewards of their principals? Logic, critique reconciliation of two conflicting theories of corporate governance, "Journal für Betriebswirtschaft" Vol. 58, Issue 3. 


\section{Management \\ 2015 \\ Vol.19, No. 2}

3. Gutenberg E. (1980), Funktionswandel des Aufsichttrafs, "Zeitschrift fun Betreibwirtschaft, Dezember.

4. Jeżak J. (2010), Rada nadzorcza a sytuacja kryzysowa w spótce [in:] Nadzór korporacyjny w warunkach kryzysu gospodarczego, Urbanek P. (ed.), Lodz University Press.

5. Urbanek P. (2005), Nadzór korporacyjny a wynagrodzenie menedżerów, Lodz University Press. 